\title{
Effect of Ursolic Acid on the Development of Mouse Embryonic Stem Cells under Hypoxia
}

\author{
Gi Yeon Han', Jae Hong Park², Keon Bong $\mathrm{Oh}^{3}{ }^{3}$ and Sei-Jung Lee ${ }^{4} \star$ \\ ${ }^{1}$ Seoul High School, Seoul 137-871, Korea, ${ }^{2}$ Maria Biotech Co., Seoul 130-812, Korea \\ ${ }^{3}$ Animal Biotechnology Division, National Institute of Animal Science, RDA, Suwon 441-706, Korea \\ ${ }^{4}$ BK21 PLUS Program for Creative Veterinary Science Research, Seoul National University, Seoul 151-741, Korea
}

Received September 5, 2013 /Revised September 30, 2013 / Accepted October 1, 2013

\begin{abstract}
Ursolic acid (UA) a bio-active ingredient found in a variety of fruits and vegetables, and it has potent antioxidant activity. However, the role of UA in mouse embryonic stem (ES) cells is poorly understood. This study investigated the functional role of UA in regulating the development of mouse ES cells under hypoxia. Hypoxia did not exert a significant effect on the undifferentiated state of mouse ES cells. However, it induced reactive oxygen species (ROS) generation and increased the level of lactate dehydrogenase (LDH) production at $48 \mathrm{~h}$ of hypoxic exposure. Conversely, oxidative stress induced by hypoxia was significantly inhibited by UA $(30 \mu \mathrm{M})$ pretreatment. Hypoxia significantly decreased cell survival and the level of $\left[{ }^{3} \mathrm{H}\right]$ thymidine incorporation, both of which recovered following pretreatment of UA. In addition, UA decreased the apoptotic effect of hypoxia by attenuating caspase-3 cleavage or by recovering cellular inhibition of the apoptotic protein (cIAP)-2 and Bcl-2 expression. We further found that UA decreased senescence-associated beta-galactosidase activity. We suggest that UA is a natural antioxidant and one of the functional modulators of hypoxia-induced survival, apoptosis, proliferation, and aging in mouse ES cells.
\end{abstract}

Key words : Apoptosis, mouse embryonic stem (ES) cells, proliferation, senescence, survival

\section{서 론}

배아줄기세포(embryonic stem cells)는 수정난 착상 이전의 발달 단계인 배반포(blastocyst)의 내세포괴(inner cell mass) 에서 회수되는 세포로, 끊임없이 자가재생(self-renewal)이 가 능하며 특정 세포로 분화할 수 있는 전능성(pluripotency)의 특징이 있다[18]. 흥미롭게도 착상전 배아는 3 5\% 저산소 상 태에 노출되어 있으며, 이러한 저산소 환경은 배반포 발달 및 배아세포의 증식에 영향을 끼쳐 배아 성장에 영향을 주는 것 으로 알려져 있다[7]. 최근에 인간배아줄기세포의 경우, $2 \%$ 정도의 생리학적 저산소 환경은 세포의 활성을 유도하고, 염 색체 이상을 감소시킴으로써 세포의 생존(survival)을 촉진시 키는 효과가 있다고 보고 되었다[8]. 그러나 산모의 고혈압, 감염, 영양실조, 약물중독 등의 다양한 상황은 태아의 지속적 인 저산소증 및 산화적 스트레스를 유발하게 되는데, 이러한

\footnotetext{
*Corresponding author

Tel : +82-2-887-2732, Fax : +82-2-885-2732

E-mail : seijung1@gmail.com

Tel : +82-31-290-1633, Fax : +82-31-290-1622

E-mail: keonoh@korea.kr

This is an Open-Access article distributed under the terms of the Creative Commons Attribution Non-Commercial License (http://creativecommons.org/licenses/by-nc/3.0) which permits unrestricted non-commercial use, distribution, and reproduction in any medium, provided the original work is properly cited.
}

저산소 및 산화적 스트레스에 대한 노출은 태아 사망의 주요 한 원인중의 하나이며 경미한 뇌손상에서부터 뇌성마비까지 다양한 신경학적 불능을 초래하고 있다[21]. 따라서 이와 같은 종합적인 결과는 세포내 전능성을 유지하기 위한 배아줄기세 포의 행동은 산소의 농도에 아주 민감하게 작동하며, 지속적 인 산화적 스트레스는 배아의 발달에 유해한 영향을 줄 수 있다는 것을 말해준다.

활성 산소종(reactive oxygen species, ROS)은 이러한 산화 적 세포손상에 있어서 중요한 매개물질로 작용하며, 여러 생 리학적 필수과정 및 질환 발생 기전에서 양면적인 특성을 가 진 잠재적 신호전달 물질로 알려져 있다[6]. 특히 배아줄기세 포에서 발생되는 활성산소종은 배아세포의 증식 및 배아의 발달 등 다양한 생리학적 조건에 영향을 주지만, 지속적인 저 산소 상태에서 발생되는 높은 농도의 활성산소종은 오히려 세포의 증식을 억제시키거나 세포자살을 유도하고, 이와 더불 어 세포의 노화를 급속히 유도하므로 배아발달에 심각한 타격 을 주는 것으로 알려져 있다 $[1,6,14]$. 따라서 지속적인 저산소 상태가 배아줄기세포에 미치는 산화적 스트레스에 대한 반응 을 알아보고, 이 결과를 바탕으로 활성산소종을 제어하는 방 법을 연구 하는 것은 배아줄기세포의 손상을 억제하고 그 전 능성을 오랫동안 유지시킬 수 있는 최소한의 방법을 제시 할 수 있을 것으로 생각된다.

우르솔산(Ursolic acid)은 로즈마리(Rosemarinus officinalis), 비파나무(Eriobotrya japonica), 히더(Calluna vulgaris), 베이질 
(Ocimum sanctum) 등의 약재 식물들의 꽃과 잎, 그리고 열매 등으부터 분리되는 pentacyclic triterpenoid로서 항염증 및 항 암 화 작용에 탁월한 효과가 있는 것으로 보고 되었다[8]. 특히 강력한 항산화 작용을 바탕으로 암세포의 성장과 침습, 전이 를 억제하는 것으로 알려졌다 $[9,10,11]$. 따라서 이러한 우르솔 산의 탁월한 약리적인 효과는 저산소상태에서 배아줄기세포 로부터 발생되는 활성산소종 및 노화 신호를 억제하는 기능성 물질로써 응용될 수 있음을 암시해준다.

따라서, 본 연구에서는 저산소환경이 배아줄기세포의 생존 과 증식 그리고 세포의 자살과 노화기전을 촉진 시킬 수 있는 지를 알아보고, 이때 우루솔산이 저산소에 의해 유도되는 배 아줄기세포의 행동기작을 조절할 수 있는지 조사하였다.

\section{재료 및 방법}

\section{시약}

본 실험에 사용된 시약 중, 소태아혈청(Fetal bovine serum, FBS)은 GIBCO-BRL (Grand Island, NY, USA)에서 구입하였 으며, Cleaved caspase-3, cIAP-2, Bcl-2, B-actin에 대한 항체는 Santa Cruz Biotechnology (Paso Robles, CA)에서 구입하였 다. 이외의 모든 시약은 Sigma사(St. Louis, MO, USA)의 제품 을 구입하여 사용하였고, 그 외 사용된 시약은 순도가 높은(순 도 $99 \%$ 이상) 등급을 구입하여 사용하였다.

\section{배아줄기세포 배양}

마우스 배아줄기세포(ES-E14TG2a)는 American Type Culture Collection (Manassas, VA)에서 구입하였으며, 고포도당 Dulbecco's modified Eagle's medium (DMEM) 배지에 15\% FBS, $1.7 \mathrm{mM}$ L-glutamine, $0.1 \mathrm{mM} \quad \beta$-mercaptoethanol, 5 $\mathrm{ng} / \mathrm{ml} \mathrm{LIF}, 100 \mathrm{U} / \mathrm{ml}$ penicilline, $100 \mu \mathrm{g} / \mathrm{ml}$ streptomycin를 혼합한 후, $37^{\circ} \mathrm{C}$ 의 $5 \% \mathrm{CO}_{2}$ incubator에서 배양하였다. 실험에 앞서 $\mathrm{FBS}$ 가 들어 있지 않은 배지로 교환하여 24시간 동안 배양 하였다. 저산소 상태 환경을 만들어 주기위해, 공기의 밀봉이 용이하고 빠른 gas 교환기능을 가진 저산소 챔버(MIC-101, Billups-Rotheberg, Del Mar, CA)를 이용하였고 이곳에 마우
스 배아줄기세포를 넣고, 저산소 상태 가스 $\left(2.2 \% \mathrm{O}_{2}, 5.5 \%\right.$ $\mathrm{CO}_{2}, 92.3 \% \mathrm{~N}_{2}$ )를 $20 \mathrm{l} / \mathrm{min}$ 으로 30분 동안 흘려 준 후, 챔버를 밀봉하여 비유동적 저산소환경(non-fluctuating hypoxic environment)을 만든 후, $37^{\circ} \mathrm{C}$ 의 세포 배양기에 넣어 지정된 시 간동안 배양하였다.

\section{Alkaline phosphatase 염색}

배아줄기세포를 Phosphate buffered saline (PBS)로 두 번 세척한 후 $4 \%$ formaldehyde로 15 분간 상온에서 고정한다. 고 정 후 PBS로 다시 두 번 세척한 후, alkaline phosphatase 혼합 용액 $(200 \mu \mathrm{g} / \mathrm{ml}$ naphthol AS-MX phosphate, 2\% N,N-dimethylformamide, $0.1 \mathrm{M}$ Tris, $\mathrm{pH} 8.2,1 \mathrm{mg} / \mathrm{ml}$ Fast Red TR salt)을 상온에서 10-15분간 처리하였다. PBS로 세척 한 후 공 초점 레이저 현미경(Olympus FluoView 300 confocal microscope, Tokyo, Japan)을 이용해 400배 배율로 세포를 관찰하 였다

$\mathrm{RNA}$ 추출 및 Reverse transcription polymerase chain reaction (RT-PCR) 분석

Trizol (Invitrogen, Carlsbad, CA)을 이용하여 총 RNA를 추출하였다. 추출된 RNA는 Maxime RT PreMix Kit (iNtRON Biotechnology, Sungnam, Kyungki, Korea)을 사용하여 cDNA 로 합성하였다. 합성된 $\mathrm{cDNA}$ 를 Table 1에 제시한 프라이머를 이용하여 증폭시켰으며, 증폭된 RT-PCR 산물은 $1 \%$ 아가로스 겔을 사용하여 전기영동으로 확인하였다.

\section{세포 내 활성산소양 측정}

배아줄기세포를 우르솔산과 함께 저산소에 노출시킨 후, 10 $\mathrm{mM}$ 의 $2^{\prime}, 7^{\prime}$-dichlorofluorescein (DCFH-DA)를 30분 동안 어 두운 곳에서 배양시키고, 공초점 레이저 현미경(Olympus FluoView 300 confocal microscope, Tokyo, Japan)을 이용해 $488 \mathrm{~nm}$ (excitation)과 515-540 nm (emission)의 파장에서 400 배 배율로 세포를 관찰하였다. 활성산소양을 정량하기위해, 세포를 차가운 PBS에서 수확하고, $100 \mu 1$ 씩 96-well flat bottom plates 분주한 후, fluorescent plate reader (Victor3;

Table 1. Primers used for polymerase chain reaction (PCR)

\begin{tabular}{cllc}
\hline Gene & Identification & Primer sequence, $5^{\prime}-3^{\prime}$ & Annealing Tm. $\left({ }^{\circ} \mathrm{C}\right)$ \\
\hline Oct-4 & Sense & CGTGAGACTTTGCAGCCTGA & 50 \\
& Antisense & GGGATGTAAGTGATCTGCTG & \\
SOX-2 & Sense & GTGGAAACTTTTGTCCGAGAC & 50 \\
& Antisense & TGGAGTGGGAGGAAGAGGTAAC & \\
FOXD3 & Sense & TCTTACATCGCGCTCATCAC & 55 \\
& Antisense & TCTTGACGAAGCAGTCGTTG & \\
3-actin & Sense & AGCCATGTACGTAGCCATCC & 55 \\
& Antisense & CTCTCAGCTGTGGTGGTGAA & \\
\end{tabular}

Abbreviations: octamer-binding transcription factor 4, Oct4; sex determining region Y box 2, SOX-2;Forkhead box protein D3, FOXD3. 
Perkin-Elmer,Waltham, MA)를 이용해 $485 \mathrm{~nm}$ (excitation)과 $535 \mathrm{~nm}$ (emission)의 파장에서 그 정량값을 얻었다.

\section{Lactate dehydrogenase 방출 분석}

배아줄기세포를 우르솔산과 함께 저산소에 노출시킨 후, lactate dehydrogenase (LDH) kit (Iatron Lab, Tokyo, Japan) 를 이용하여 활성산소종에의해 발생되는 세포막 손상의 정도 [20]를 측정하였다. 약 $25 \mu \mathrm{l}$ 세포 배양액을 $75 \mu \mathrm{LDH}$ 기질 혼합물에 넣고, 1 시간 동안 상온에서 반응시킨 후 $570 \mathrm{~nm}$ 에서 그 흡광도를 측정하였다. $\mathrm{LDH}$ 측정값은 대조군에 대한 \%로 계산하였다.

\section{$\left[{ }^{3} \mathrm{H}\right]$-thymidine 결합 측정}

$\left[{ }^{3} \mathrm{H}\right]$-thymidine 결합 측정은 Brett (1993)가 발표한 방법[4] 을 이용하였다. 배아줄기세포를 우르솔산과 함께 저산소에 노 출시킨 후, $1 \mu \mathrm{Ci}$ 의 [methyl- ${ }^{3} \mathrm{H}$ ]-thymidine (Amersham Biosciences, Buckinghamshire, $\mathrm{UK})$ 를 처리하여 $37^{\circ} \mathrm{C}$ 에서 1시 간 동안 배양 시켰다. 용출물속의 방사선 활성도를 liquid scintillation counter (Wallac, Turku, Finland)로 측정하였고, 실험 결과는 대조군에 대한 \%로 계산하였다.

\section{$\mathrm{MTT}$ 분석}

배아줄기세포를 우르솔산과 함께 저산소에 노출시킨 후, 3-(4,5-dimethylthiazol-2-yl)-2,5 diphenyl tetrazolium bromide (MTT)를 처리하고 2시간 동안 $\mathrm{CO}_{2}$ 세포배양기에서 배양하였 다. 배양 후 형성된 자색의 formazen 결정을 육안 및 현미경을 이용해 관찰하고 세포를 PBS를 이용하여 2번 세척하였다. 500 $\mu \mathrm{l}$ 의 Dimethyl sulfoxide (DMSO)를 2시간 동안 배양하여 formazen을 완전히 용해시킨 후, $200 \mu \mathrm{l}$ 씩 96-well flat bottom plates 분주하여 $570 \mathrm{~nm}$ 에서 그 흡광도를 측정하였다

\section{Western blot 분석}

Western blot 실험을 수행하기 위하여, 배아줄기세포에 지 정된 농도와 시간에 따라 우르솔산을 처리하고, PBS로 잘 세 척한 후, whole 세포 단백질을 추출하였다. Whole 세포 단백 질은 protease inhibitor cocktail (Boehringer, Mannheim)이 포함된 lysis buffer (20 mM HEPES, $\mathrm{pH} 7.9,400 \mathrm{mM} \mathrm{NaCl}$, $0.2 \mathrm{mM}$ EDTA, $1 \mathrm{mM}$ DTT, $1 \mathrm{mM}$ PMSF in isopropanol, $1.5 \mathrm{mM} \mathrm{MgCl} 2,25 \%$ glycerol, $0.5 \% \mathrm{NP}-40$ )에서 추출되었고, Bradford 방법[3]을 이용하여 단백질의 농도를 확인하였다. 정 량된 단백질들을 $10 \%$ polyacrylamide gel에 $100 \mathrm{~V}, 30 \mathrm{~mA}$ 에 서 $2.5 \mathrm{~h}$ 동안 전기영동 하였고, $\mathrm{PVDF}$ membrane에 transfer시 킨 후, $5 \%$ 탈지분유가 함유된 TBS-Tween 용액(25 mM Tris base, $137 \mathrm{mM} \mathrm{NaCl}, 2.68 \mathrm{mM} \mathrm{KCl}, 0.05 \%$ Tween-20, pH 7.5) 으로 $25^{\circ} \mathrm{C}$ 에서 1 시간 동안 반응시켰다. 3,000 배 희석된 primary antibody (cleaved caspase-3, cIAP-2, Bcl-2, $\beta$-actin)와
10,000 배 희석된 secondary antibody를 적당한 시간 동안 순차 적으로 처리하고, chemiluminescence 기계(Amersham Pharmacia Biotech, Buckinghamshire, UK)를 이용해 cleaved caspase-3, cIAP-2, Bcl-2, $\beta$-actin의 발현을 확인하였다

\section{$\beta$-galactosidase 활성 측정}

노화된 세포에서 특징적으로 발현되는 $\beta$-galactosidase의 활성을 측정하기 위해 senecence-associated $\beta$-galactosidase kit (SA- $\beta$-gal, Sigma, St Louis, MO, USA)을 이용하였다. 배아 줄기세포를 PBS로 두 번 세척한 후 $4 \%$ formaldehyde로 15 분 간 상온에서 고정한 다음, $\beta$-galactosidase 활성 측정 혼합물을 넣어 12시간까지 배양하였다. 광학현미경으로 $\beta$-galactosidase 양성인 푸르게 염색된 노화된 세포수와 전체 세포수를 세어서 노화된 세포의 정도를 계산하였다.

\section{통계처리}

모든 실험은 3회 이상 반복 하였으며, 실험결과는 means \pm $\mathrm{SE}$ 로 표현 하였다. 유의적 차이는 Student's test 및 one-way analysis of variance (ANOVA) 이용하여 결정하였으며, $\mathrm{p}$-values < 0.05 의 값들을 유의적인 결과로 고려하였다.

\section{결과 및 고찰}

\section{저산소가 배아줄기세포 미분화에 미치는 영향}

저산소 환경이 배아줄기세포의 미분화 상태 및 전능성에 미치는 효과를 알아보기 위해, 48 시간 동안 배아줄기세포를 저산소에 노출시킨 후, 미분화 마커인 alkaline phosphatase (AP) 효소의 활성을 측정하였다. 흥미롭게도 배아줄기세포의 $\mathrm{AP}$ 활성을 나타내는 적자색의 콜로니들이 48 시간 동안의 저 산소 환경의 노출에도 불구하고 계속 관찰됨을 알 수 있었다 (Fig. 1A). AP는 phosphate monoester를 가수분해하는 특성 을 가진 세포막 결합 효소로서 DNA가 합성되는것을 막아줄 뿐만 아니라, 주로 자가 재생과 분화를 조절하는 전사인자인 Oct4, SOX-2, Klf4, c-Myc 등의 발현 조절에 영향을 주어 배아 줄기세포의 전능성을 유지하는 대표적인 마커로 알려져 있다 $[15,23]$. 저산소 환경이 배아 줄기세포의 자가재생과 분화를 조절하는 전사인자인 Oct4 (octamer-binding transcription factor 4), SOX-2 (sex determining region $Y$ box-2), 그리고 FOXD3 (forkhead box family member) 유전자발현에 미치는 효과에 대해 추가적으로 알아보았다. 이러한 전사인자들은 일 반적으로 외부의 자극이 있는 경우, 유전자 발현을 On/Off 할 수 있는 '스위치' 역할, 즉 자가 재생에 관련된 유전자를 활성화 시키고 분화 유전자는 억제 시킴으로써 배아줄기세포 로 하여금 전능성을 유지하도록 하는 것으로 알려져 있다[10]. Fig. $1 \mathrm{~A}$ 에서 보는 바와 같이, 배아줄기세포를 48 시간 동안 저 
A

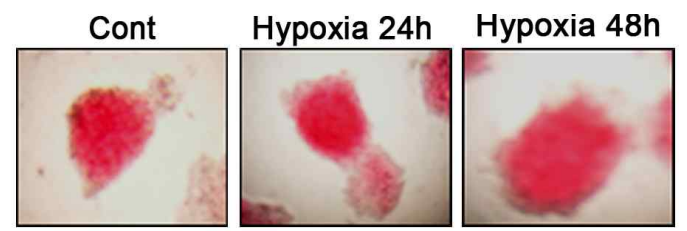

B

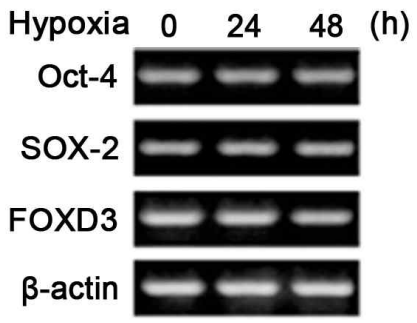

Fig. 1. Effect of hypoxia on mouse ES cells characteristics. (A) AP enzyme activity was assessed in mouse ES cells under hypoxic condition for either 24 or $48 \mathrm{~h}$. Magnification, 400X. AP, Alkaline phosphatase; Cont, Control. Representative images from 3 separate experiments are shown $(n=3)$. (B) mouse ES cells were exposed to hypoxia for $48 \mathrm{~h}$. Total RNA from mouse ES cells was reverse transcribed, and Oct-4, SOX-2, FOXD3, and $\beta$-actin cDNA were amplified by real-time PCR. $n=3$.

산소에 노출한 후에도 이들 미분화 유전자들의 mRNA의 발현 에는 차이가 나지 않았다. 따라서 이러한 결과는 48 시간 동안 의 저산소 환경은 배아줄기세포의 미분화상태 및 전능성을 유지하는데 있어서 유의적 영향을 미치치 않음을 알 수 있다.

저 산소가 세포 활성산소 생성 및 세포 손상에 미치는 영향

\section{및 우르솔산 효과}

한편 일반적으로 대부분 생물체의 정상적인 대사과정에서 불가피하게 발생되는 활성 산소종 $\left(\mathrm{O}_{2}{ }^{-}, \mathrm{H}_{2} \mathrm{O}_{2}, \cdot \mathrm{OH}, \mathrm{NO}^{-}\right.$, $\mathrm{ONOO})$ 은 생체 내에 존재하는 여러 항산화 효소에 의해 소멸 되거나 제거되기 때문에 생명현상에는 큰 문제가 되지 않지 만, 저산소환경을 포함한 여러 유해 인자로 인해 비이상적으 로 과잉 생성된 활성 산소종은 세포막 지방의 산화, 단백질의 산화 및 변성, DNA 변성 등을 일으킴으로써 세포의 노화를 유도하거나, 세포의 증식을 억제시키거나 세포자살을 유도하 여 배아발달 심각한 타격을 주는것으로 알려져 있다 $[1,6,14]$. Fig. 2의 형광염색사진(Fig. 2A)과 이를 정량한 결과(Fig. 2B)에 서 보는 바와 같이, 배아줄기세포를 저산소 환경에 48 시간 동 안 노출시켰을때, 대조군에 비해 활성 산소종의 농도가 $70 \%$ 이상 증가한 반면, $30 \mu \mathrm{M}$ 의 우르솔산의 처리는 항산화제인 $\mathrm{N}$-acetyl-cysteine (NAC) 전 처리 한 것과 비슷한 수준으로 저산소에 의한 활성 산소종 증가를 현저히 감소시키는 항산화 효과를 보여주었다. 그러나 예비연구결과 낮은 농도(1과 10 $\mu \mathrm{M})$ 의 우르솔산은 저산소에의해 발생된 활성 산소종을 억제 하지 못했다. 특히 활성 산소종에의해 발생되는 세포막 손상 의 마커인 lactate dehydrogenase $(\mathrm{LDH})$ 방출은 대조군에 비 해 저산소 처리군에서 $40 \%$ 이상 증가한 반면, $30 \mu \mathrm{M}$ 의 우르솔 산의 처리는 $\mathrm{LDH}$ 방출을 정상수준으로 유의적으로 감소시켰 다. 따라서 생리활성 물질로서 우루솔산은 지속적인 저산소환 경에서 발생된 배아줄기세포의 활성 산소종 발생을 막고, 이 와 더불어 세포막 손상을 포함한 산화적 스트레스를 억제하는 항산화제로서 그 역할을 할 것으로 생각된다.

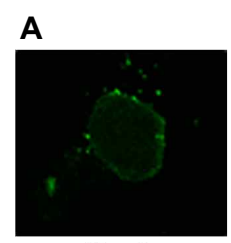

Cont

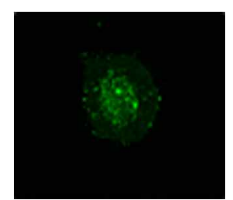

Hypoxia

+ UA

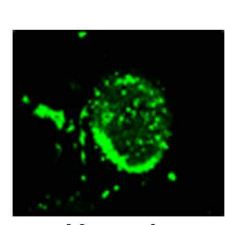

Hypoxia

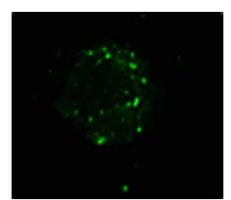

Hypoxia

+ NAC
B

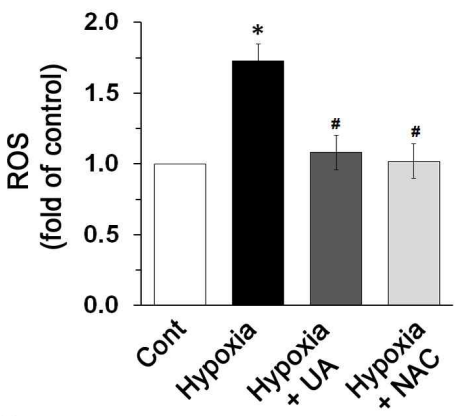

C

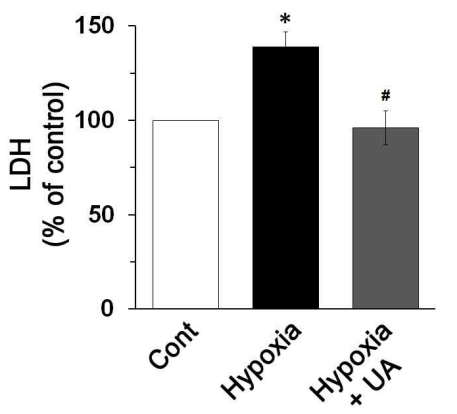

Fig. 2. Ursolic acid has inhibitory effect on hypoxia-induced ROS generation and LDH production in mouse ES cells. Mouse ES cells were pretreated with UA $(30 \mu \mathrm{M})$ or NAC $(10 \mu \mathrm{M})$ for $30 \mathrm{~min}$ and exposed to the hypoxic condition for 48 h. (A) Dichlorofluorescein- sensitive cellular ROS (green) were observed by using immunofluorescence confocal microscopy. Magnification, 400X. $n=3$. (B) Dichlorofluoresceinsensitive cellular ROS were observed by luminometry. Error bars represent the means \pm SE from three independent experiments involving triplicates. ${ }^{*}, p<0.01$ versus normoxia. \#, $p<0.01$ versus hypoxia. (C) LDH released into cell culture media was determined as described in Materials and Methods section. Error bars represent the means + SE from three independent experiments involving triplicates. ${ }^{*}, p<0.05$ versus normoxia. ${ }^{\#}, p<$ 0.05 versus hypoxia 
저 산소가 세포 생존 및 DNA 합성에 미치는 영향 및 우르 솔산 효과

저산소환경에 의해 유발된 고농도의 활성산소종은 배아줄 기세포의 생사에 영향을 끼칠 것이라는 예상을 가지고, MTT 분석과 $\left[{ }^{3} \mathrm{H}\right]$-thymidine 방법을 이용해 우르솔산의 유용한 효 과를 조사하였다. 배아줄기세포를 저산소 환경에 48 시간 동안 노출시켰을때, 세포의 생존율(Fig. 3A)과 세포의 증식(Fig. 3B) 은 대조군에 비해 $40 \%$ 그리고 $80 \%$ 이상 각각 감소한 반면, $30 \mu \mathrm{M}$ 의 우르솔산의 처리는 대조군과 비슷한 수준으로 저산 소에 의한 세포 생존율및 증식율을 유지시키는 효과를 보여주 었다. MTT는 세포 내에서 미토콘드리아에 존재하는 효소에 의해 환원되어 불용성의 자색을 나타내는 formazen을 형성하 게 되는 것을 이용하여 세포의 생존을 측정하는 반면, $\left[{ }^{3} \mathrm{H}\right]$-thymidine은 세포유사분열 동안, 새롭게 합성되는 chromosomal DNA에 삽입되는것을 이용하여 세포의 증식 유무를 판단할 수 있다. 따라서 이와 같은 결과는 탁월한 항산화능력 을 가진 우르솔산은 세포 미토콘드리아와 관련된 생리학적 $\mathrm{ATP}$ 생성과정이나 핵 내의 DNA합성과정을 조절하므로서 배 아줄기세포의 전능력 유지에 중요한 역할을 할 수 있는 가능 성을 암시한다.

한편 우르솔산은 저산소 환경에 의해 유도된 배아줄기세포 의 자살을 억제하는 효과를 보여 주었다(Fig. 3C). 세포자살은 생리적으로 발생하는 예정된 세포의 죽음으로 다른 세포에 손상을 주지 않고 원치 않는 세포가 제거되는 자연 과정을 말한다[19]. 특히 caspase는 세포자살 과정에서 실행경로의 활 성화 과정에 관여하는 중요한 단백질 분해효소이므로 이 효소 의 활성도를 측정하여 세포의 자살 유무를 판단 할 수 있다
[22]. 배아줄기세포를 저산소 환경에 48 시간 동안 노출시켰을 때, pro-caspase활성 증가로 인해 cleaved caspase-3의 발현이 증가한 반면, $30 \mu \mathrm{M}$ 의 우르솔산의 처리는 대조군과 비슷한 수준으로 cleaved caspase-3의 발현을 낮추는 효과를 보여주 었다. 한편 저산소 환경은 caspase 효소에 결합하여 그 활성을 억제하는 cIAP (cellular inhibition of apoptosis protein)-2의 발현[16]을 억제했을 뿐만 아니라, 미토콘드리아에 의한 intrinsic apoptosis pathway에 작용하는 anti-apoptosis와 관련 있는 단백질인 Bcl-2의 발현[12]을 억제 시켰다. 그러나 우르솔 산의 처리는 저산소에 유도된 이러한 세포자살 억제단백질들 (cIAP 및 $\mathrm{Bcl}-2$ )의 발현을 유의적으로 증가시킴으로서 배아줄 기세포의 자살을 억제하는 효과를 보여주었다. 이와 같은 결 과는, 우르솔산은 강력한 항산화력을 바탕으로 저산소에 의해 일어날 수 있는 배아줄기세포의 내재적/외재적 세포자살 기 작을 낮추고, 궁극적으로 배아줄기세포를 자가 복제 능력 및 전분화능을 갖춘 세포로서 온전하게 보호할 수 있는 능력을 가지고 있는 기능성 물질임을 암시한다.

\section{저 산소가 세포 노화에 미치는 영향 및 우르솔산 효과}

노화란 시간에 따른 생체 기능의 손실을 의미하는데, 생명 의 지속과 나란히 겪게 되는 피할 수 없는 현상이다[9]. 특히 활성 산소종은 노화의 기본적인 원인 물질로서, 그 반감기는 짧지만 반응성이 매우 강하여 세포의 구성물질인 고분자 물질 즉 단백질, 지질, $\mathrm{DNA}$ 를 공격하여 부서뜨리거나 변형시킨다 [5]. 특히 배아 줄기 세포의 경우, 단백질 및 지질은 대사과정에 서 계속 만들어지기 때문에 어느정도 재생이 가능하지만, 핵 이나 미토콘드리아에 있는 유전정보 보관물질인 DNA는 복구
A
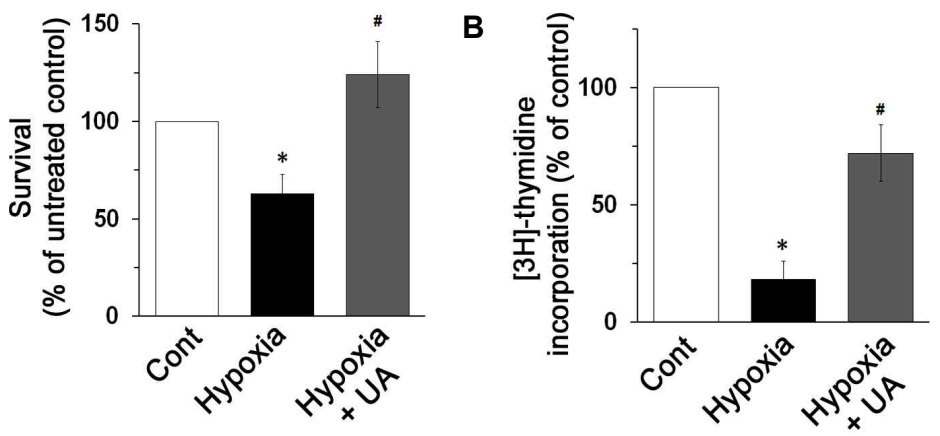

C

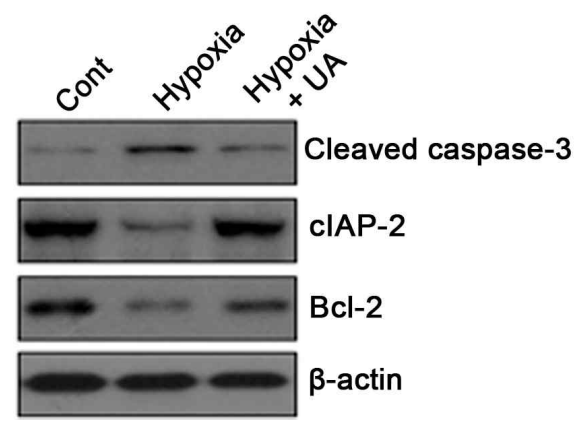

Fig. 3. Ursolic acid has inhibitory effect on hypoxia-induced apoptosis in mouse ES cells. Mouse ES cells were pretreated with UA $(30 \mu \mathrm{M})$ for 30 $\mathrm{min}$ and exposed to the hypoxic condition for $48 \mathrm{~h}$. Cell survivals (A) and proliferation (B) were evaluated by the MTT and $\left[{ }^{3} \mathrm{H}\right]$-thymidine incorporation assay, respectively. Error bars represent the means \pm SE from three independent experiments involving triplicates. *, $p<0.05$ versus normoxia. \#, $p<0.05$ versus hypoxia. (C) The total cell lysates were subjected to SDS-PAGE and cleaved caspase-3, cIAP-2, and $\mathrm{Bcl}-2$ were detected by using western blot. $\beta$ actin expression is shown as controls. Representative images from 3 separate experiments are shown $(n=3)$. 


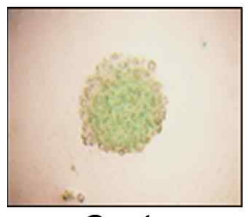

Cont

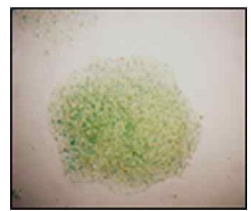

Hypoxia

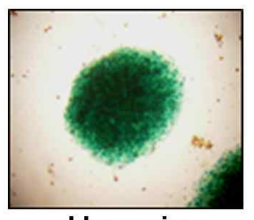

Hypoxia

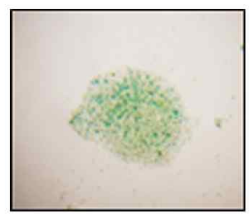

Hypoxia

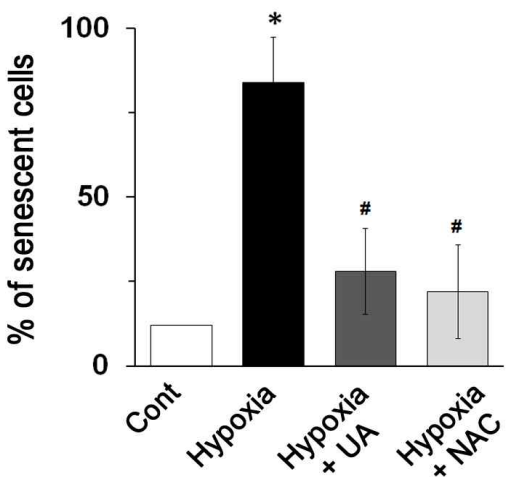

Fig. 4. Ursolic acid has inhibitory effect on hypoxia-induced senescence in mouse ES cells. Mouse ES cells were pretreated with UA $(30 \mu \mathrm{M})$ or NAC $(10 \mu \mathrm{M})$ for $30 \mathrm{~min}$ and exposed to the hypoxic condition for $48 \mathrm{~h}$. (A) Senescence-associated beta-galactosidase activity (blue) was observed by using immunofluorescence confocal microscopy. Magnification, 400X. n=3. (B) Senescence-associated beta-galactosidase activity was determined as \% of senescent cells. Error bars represent the means \pm SE from three independent experiments involving triplicates. ${ }^{*}, p<0.01$ versus normoxia. ${ }^{*}, p<0.01$ versus hypoxia.

가 불가능하며, 배아의 발달에 치명적인 영향을 줄 수 있다 [17]. 따라서 배아줄기세포는 노화에 아주 민감한 세포라고 알 려져 있으며, 그 특징을 살펴보자면, 모두 일정한 회수의 분열 을 한 뒤에 멈춰서 더 이상 분열하지 않고 세포의 모양이 넓게 퍼지고, 그 크기가 커지면서, SenA-beta-gal (senescence associated beta-galactosidase)에 의해 핵 주위가 파랗게 염색되는 세포로 바뀌는 복제적 노화(replicative senescence) 현상을 보 여준다[11]. Fig. 4에서 보는 바와 같이, beta-galactosidase 활 성을 나타내는 푸른색의 콜로니가 저산소 환경 48 시간 후에 유의적으로 증가됨이 관찰되었지만, 우르솔산의 처리는 저산 소에 유도된 배아줄기세포의 노화를 유의적으로 억제하는 효 과를 보여주었다. 이것은 우르솔산의 탁월한 약리학적 효과가 저산소 상태로부터 지속적으로 발생되는 활성산소종 및 노화 신호를 억제하고, 이를 통해 배아줄기세포의 분열능력 및 자 가증식 능력을 유지하는데 도움을 줄 것으로 생각할 수 있다.

지금까지의 연구를 종합해 볼때, 저산소 환경은 배아줄기세 포의 미분화상태 및 전능성을 유지에 있어서 영향을 미치지 않았지만, 세포내 활성산소종의 지속적인 생산으로 인해 산화 적 스트레스를 유도하였다. 이로 인해 세포의 생존과 증식을 감소 시켰을 뿐만 아니라, 세포의 자살 및 노화를 유도하였다. 그러나 우르솔산의 강력한 활성산소 소거능력은 저산소상태 에서 배아줄기세포로부터 나타나는 유해 행동기작을 제어함 으로서, 배아줄기세포의 전능성을 유지시킬 수 있는 탁월한 약리학적 가능성을 가지고 있었다. 향후 우르솔산의 배아줄기 세포 행동 조절기전에 대한 분자생물학적인 연구로서 hypoxia inducible factor의 조절기작에 대한 실험이 더 필요하며, 산화적 스트레스에 의한 배아줄기세포 유해 메커니즘을 더욱 이해하는 연구가 수행되어야 할 것이다.

\section{감사의 글}

본 논문은 농촌진흥청 차세대 바이오그린21사업(과제번호: PJ009090)의 지원에 의해 이루어진 것임.

\section{References}

1. Agarwal, A., Gupta, S. and Sharma, R. K. 2005. Role of oxidative stress in female reproduction. Reprod Biol Endocrinol $14,28$.

2. Aggarwal, B. B. and Shishodia, S. 2006. Molecular targets of dietary agents for prevention and therapy of cancer. Biochem Pharmacol 14, 1397-1421.

3. Bradford, M. M. 1976. A rapid and sensitive method for the quantitation of microgram quantities of protein utilizing the principle of protein-dye binding. Anal Biochem 7, 248-254.

4. Brett, C. M., Washington, C. B., Ott, R. J., Gutierrez, M. M. and Giacomini, K. M. 1993. Interaction of nucleoside analogues with the sodium-nucleoside transport system in brush border membrane vesicles from human kidney. Pharm Res 10, 423-426.

5. Chung, H. Y., Sung, B., Jung, K. J., Zou, Y. and Yu, B. P. 2006. The molecular inflammatory process in aging. Antioxid Redox Signal 8, 572-581.

6. Csete, M. 2005. Oxygen in the cultivation of stem cells. Ann $N Y$ Acad Sci 1049, 1-8 .

7. Fischer, B. and Bavister, B. D. 1993. Oxygen tension in the oviduct and uterus of rhesus monkeys, hamsters and rabbits. J Reprod Fertil 99, 673-679.

8. Forsyth, N. R., Musio, A., Vezzoni, P., Simpson, A. H., Noble, B. S. and McWhir, J. 2006. Physiologic oxygen enhances human embryonic stem cell clonal recovery and reduces chromosomal abnormalities. Cloning Stem Cells 8, 16-23.

9. Harman, D. 1956. Aging: A theory based on free radical and 
radiation chemistry. J Gerontol 11, 298-300.

10. Koestenbauer, S., Zech, N. H., Juch, H., Vanderzwalmen, P., Schoonjans, L. and Dohr, G. 2006. Embryonic stem cells: similarities and differences between human and murine embryonic stem cells. Am J Reprod Immunol 55, 169-180.

11. Lee, B. Y., Han, J. A., Im, J. S., Morrone, A., Johung, K., Goodwin, E. C., Kleijer, W. J., DiMaio, D. and Hwang, E. S. 2006. Senescence-associated beta-galactosidase is lysosomal beta-galactosidase. Aging Cell 5, 187-195.

12. Lessene, G., Czabotar, P. E. and Colman, P. M. 2008. BCL-2 family antagonists for cancer therapy. Nat Rev Drug Discov 7, 989-1000.

13. Liu, J. 1995. Pharmacology of oleanolic acid and ursolic acid. J Ethnopharmacol 1, 57-68.

14. Martin, I. and Grotewiel, M. S. 2006. Oxidative damage and age-related functional declines. Mech Ageing Dev 127, 411423 .

15. Maxam, A. M. and Gilbert, W. 1980. Sequencing end-labeled DNA with base-specific chemical cleavages. Methods Enzymol 65, 499-560.

16. Moon, D. O., Park, S. Y., Heo, M. S., Kim, K. C., Park, C., Ko, W. S., Choi, Y. H. and Kim, G. Y. 2006. Key regulators in bee venom-induced apoptosis are Bcl-2 and caspase-3 in human leukemic U937 cells through downregulation of ERK and Akt. Int Immunopharmacol 5, 1796-1807.

17. Nijnik, A., Woodbine, L., Marchetti, C., Dawson, S., Lambe, T., Liu, C., Rodrigues, N. P., Crockford, T. L., Cabuy, E., Vindigni, A., Enver, T., Bell, J. I., Slijepcevic, P., Goodnow, C. C., Jeggo, P. A. and Cornall, R. J. 2007. DNA repair is limiting for haematopoietic stem cells during ageing. Nature 7, 686-690.

18. Niwa, H. 2001. Molecular mechanism to maintain stem cell renewal of ES cells. Cell Struct Funct 26, 137-148.

19. Pathak, A. K., Bhutani, M., Nair, A. S., Ahn, K. S., Chakraborty, A., Kadara, H., Guha, S., Sethi, G. and Aggarwal, B. B. 2007. Ursolic acid inhibits STAT3 activation pathway leading to suppression of proliferation and chemosensitization of human multiple myeloma cells. Mol Cancer Res 5, 943-955.

20. Roig, R., Cascón, E., Arola, L., Bladé, C. and Salvadó, M. J. 2002. Procyanidins protect Fao cells against hydrogen peroxide-induced oxidative stress. Biochim Biophys Acta 15, 25-30.

21. Saikumar, P., Dong, Z., Weinberg, J. M. and Venkatachalam, M. A. 1998. Mechanisms of cell death in hypoxia/reoxygenation injury. Oncogene 17, 3341-3349.

22. Simon, H. U., Haj-Yehia, A. and Levi-Schaffer, F. 2000. Role of reactive oxygen species (ROS) in apoptosis induction. Apoptosis 5, 415-418.

23. Ye, Z., Zhan, H., Mali, P., Dowey, S., Williams, D. M., Jang, Y. Y., Dang, C. V., Spivak, J. L., Moliterno, A. R. and Cheng, L. 2009. Human-induced pluripotent stem cells from blood cells of healthy donors and patients with acquired blood disorders. Blood 24, 5473-5480.

24. Zhang, Y., Kong, C., Zeng, Y., Wang, L., Li, Z., Wang, H., $\mathrm{Xu}, \mathrm{C}$. and Sun, Y. 2010. Ursolic acid induces PC-3 cell apoptosis via activation of JNK and inhibition of Akt pathways in vitro. Mol Carcinog 49, 374-385.

초록 : 저산소 상태에서 우르솔산이 배아줄기세포 성장에 미치는 효과

한기연 ${ }^{1} \cdot$ 박재홍 $^{2} \cdot$ 오건봉 $^{3} \cdot$ 이세중 ${ }^{*}$

( ${ }^{1}$ 서울고등학교, ${ }^{2}$ (주)마리아 바이오텍, ${ }^{3}$ 국립축산과학 원, ${ }^{4}$ 서울대학교 BK21플러스 수의창의인력양성사업단)

우르솔산(Ursolic acid)은 다양한 약재, 과일 그리고 야채 등으로 부터 분리되는 식물성 생리활성물질로서, 천연 항산화제로 널리 알려져 있지만, 배아줄기세포에서 우르솔산의 기능에 대한 연구는 아직까지 잘 이해되지 않고 있다. 본 연구에서는 저산소 상태에서 우르솔산이 배아줄기세포의 성장에 미치는 효과에 대해 조사하였다. 48 시간 동안의 저산소 환경은 배아줄기세포의 미분화상태 및 전능성을 유지에 있어서 영향을 미치지 않았지만, 세포 내 활성산소종의 지속적인 생산과 이로 인한 lactate dehydrogenase 활성을 촉진 시켰다. 저산소에 의해 유도된 배아 줄기세포의 산화적 스트레스는 $30 \mu \mathrm{M}$ 의 우르솔산의 처리로 인해 유의적으로 감소되었으며, 이러한 우르솔산의 활성산소 소거능력은 항산화제인 N-acetyl-cysteine (NAC)의 효과와 유사하였다. 저산소 환경은 또한 유의적으로 배아줄기세포의 생존과 증식을 감소 시킬 뿐만 아니라, 세포의 자살 및 노화를 유도함이 관찰되었지만, 강한 항산 화 능력을 지닌 우르솔산은 세포를 저산소로부터 보호하여 정상수준으로 세포의 생존과 증식을 유지시키고, 세포 자살 관련 단백질(cleaved caspase-3, Bcl-2, 그리고 cIAP) 및 세포 노화 관련 단백질(beta-galactosidase)을 조절하 는 탁월한 약리학적 효과를 가지고 있었다. 따라서 본 연구결과를 통해, 우르솔산은 강력한 천연 항산화제이며, 저산소에 의해 유도된 유해 기작을 제어함으로서, 배아줄기세포의 전능성을 유지시킬 수 있는 기능성 물질이라는 것을 알 수 있었다. 